\title{
A Review on Various Aspects of Jarosite and Its Utilization Potentials
}

\author{
Nasim Eftekhari ${ }^{1}$, Mohammad Kargar ${ }^{2 *}$, Farokh Rokhbakhsh Zamin ${ }^{1}$, Nahid Rastakhiz ${ }^{3}$, Zahra Manafi ${ }^{4}$ \\ ${ }^{1}$ Department of Microbiology, Kerman Branch, Islamic Azad University, Kerman 7635131167, Iran \\ ${ }^{2}$ Department of Microbiology, Jahrom Branch, Islamic Azad University, Jahrom 7414785318, Iran \\ ${ }^{3}$ Department of Chemistry, Kerman Branch, Islamic Azad University, Kerman 7414785318, Iran \\ ${ }^{4}$ Hydrometallurgy Research Unit, Research and Development Center, Sarcheshmeh Copper Complex, 144, Rafsanjan, Iran
}

Corresponding Author Email: mkargar@jia.ac.ir

https://doi.org/10.18280/acsm.440106

Received: 15 November 2019

Accepted: 28 January 2020

\section{Keywords:}

jarosite, iron, A. ferrooxidans, biooxidation, bioleaching

\begin{abstract}
Jarosite is an effective scavenger for metals by the chemical formula $\mathrm{AFe}_{3}\left(\mathrm{SO}_{4}\right)_{2}(\mathrm{OH})_{6}$ In the present article, a comprehensive literature review is performed on the formation, decomposition, and utilization of jarosite. Based on reviewed studies, biological jarosite seeds can shorten the induction period and reduce the temperature limit in the jarosite precipitation. Also, the precipitation process of jarosite is more complete with biological jarosite seeds. The crystallization parameters such as $\mathrm{Fe}_{2}\left(\mathrm{SO}_{4}\right)_{3}$ concentration, agitation speed, $\mathrm{pH}$ and temperature have significantly affected on the morphology and the particles size of jarosite. Decomposition of jarosite is carried out using two different methods thermal and hydrothermal. Jarosite seed is a potential resource, which has to be recycled in a technically feasible and environmentally friendly manner. Besides, it is observed that jarosites have several advantages such as control iron in hydrometallurgy, zinc industry, arsenic removal and other impurities, pigment, nanoparticles, filling materials, adsorption materials, acidic reagent, and catalytic materials.
\end{abstract}

\section{INTRODUCTION}

Many studies have focused on efficiency-enhancing of removal systems and obtaining better working conditions. Among various methods applied in removal efficiency enhancement such optimizing working condition and utilizing more appropriate materials [1-4]. Jarosite is a promising approach and it is an effective scavenger for metals in iron and sulfate rich acidic solutions. In 1852, German mineralogist August Breithaupt first discovered a yellowish-brown iron sulfate hydroxide mineral in Barranco del Jaroso (Jaroso Ravine) in the Sierra Almagrera along the southeastern coast of Spain and named it jarosite [1].

Jarosites [complex basic iron sulfate] are a family of minerals by the general formula $\mathrm{AB}_{3}\left(\mathrm{XO}_{4}\right)_{2}(\mathrm{OH}) \mathrm{n} \cdot \mathrm{mH}_{2} \mathrm{O}$. For jarosites, $\mathrm{B}=\mathrm{Fe}^{3+}, \mathrm{X}=\mathrm{S}, \mathrm{n}=6$. Diverse jarosite group minerals are formed based on the substitution of $\mathrm{A}$ with cations. The $\mathrm{A}$ sites can be occupied by monovalent $\left(\mathrm{K}, \mathrm{Na}, \mathrm{Ag}, \mathrm{Tl}, \mathrm{H}_{3} \mathrm{O}\right)$, divalent $(\mathrm{Ca}, \mathrm{Sr}, \mathrm{Ba}, \mathrm{Pb})$, trivalent and quadrivalent (Th, $\mathrm{U}$ ) ions [1-3]. Their mineral names, synthetic equivalents, the substitution of A and formulas are listed in Table 1. The word "jarosite" refers to the potassium form of the compound $\mathrm{KFe}_{3}\left(\mathrm{SO}_{4}\right)_{2}(\mathrm{OH})_{6}$, nevertheless all the minerals in this group are mentioned to as jarosites. Jarosites are found in acid sulfate soils, fluvial environments contaminated by acid rock (ARD) or acid mine drainage (AMD) sediments, mine tailings of sulfide ores deposits, or as a byproduct in refining and hydrometallurgical processes. In 2004, jarosite was also detected by the Mars Exploration Rover (MER) Mossbauer spectrometer $[2,4]$
The major quantity of jarosite is generated mainly from Korea, Mexico, Norway, Finland, Germany, Spain, Holland, Canada, France, Australia, Yugoslavia, Argentina, Japan and Belgium. Jarosites are produced both biologically [5-10] and chemically $[9,11,12]$. Although biologically and chemically synthesized samples show some variation in their physical properties, chemical analysis helps to identify and categorize each type. Sodium jarosite and ammonium jarosite are costeffective than potassium jarosite and therefore, more commonly used in industry $[2,3]$.

The utilization of jarosite has several advantages, such as easy operation and obvious economic benefits.

The main advantage of precipitating jarosite compounds is the high precipitation efficiency and ease of filtration. In addition, it allows the process to be carried out at lower temperature and in slightly acidic media which avoids the neutralization step. Specifically for the zinc industry, another advantage of this precipitation is that the formation of jarosite will also scavenge other impurities such as lead and silver from the zinc product, improving the quality of the product $[2$, $9,13,14]$

With a view to compensate the high cost of iron removal by jarosite precipitation, engineers and researchers focused on the utilization of jarosite precipitates as a raw material in the production of pigments and construction materials $[2,13,14]$

Some studies are available on preparation and characterization of synthetic jarosites; however, no studies focused on various aspects and utilization of jarosites have been published yet. In this work, we studied the various aspects related to jarosite and its utilization potentials. 
Table 1. Minerals of the jarosite subgroup and their synthetic equivalents

\begin{tabular}{|c|c|c|c|}
\hline Cations & Mineral name & Synthetic equivalent & Formula \\
\hline $\mathrm{K}^{+}$ & jarosite & Potassium jarosite & $\mathrm{KFe}_{3}\left(\mathrm{SO}_{4}\right)_{2}(\mathrm{OH})_{6}$ \\
\hline $\mathrm{NH}_{4}^{+}$ & ammoniojarosite & ammonium jarosite & $\left(\mathrm{NH}_{4}\right) \mathrm{Fe}_{3}\left(\mathrm{SO}_{4}\right)_{2}(\mathrm{OH})_{6}$ \\
\hline $\mathrm{Na}^{+}$ & natrojarosite & sodium jarosite & $\mathrm{NaFe}_{3}\left(\mathrm{SO}_{4}\right)_{2}(\mathrm{OH})_{6}$ \\
\hline $\mathrm{H}_{3} \mathrm{O}^{+}$ & hydronium jarosite & Hydronium jarosite & $\left(\mathrm{H}_{3} \mathrm{O}\right) \mathrm{Fe}_{3}\left(\mathrm{SO}_{4}\right)_{2}(\mathrm{OH})_{6}$ \\
\hline $\mathrm{Tl}^{+}$ & dorallcharite & Thallium jarosite & $\mathrm{TIFe}_{3}\left(\mathrm{SO}_{4}\right)_{2}(\mathrm{OH})_{6}$ \\
\hline $\mathrm{Ag}^{+}$ & argentojarosite & silver jarosite & $\mathrm{AgFe}_{3}\left(\mathrm{SO}_{4}\right)_{2}(\mathrm{OH})_{6}$ \\
\hline $0.5 \mathrm{~Pb}^{2+}$ & plumbojarosite & lead jarosite & $\mathrm{PbFe}_{6}\left(\mathrm{SO}_{4}\right)_{2}(\mathrm{OH})_{12}$ \\
\hline $0.5 \mathrm{Hg}^{2+}$ & no mineral equivalent & mercury jarosite & $\mathrm{HgFe}_{6}\left(\mathrm{SO}_{4}\right)_{4}(\mathrm{OH})_{12}$ \\
\hline $\mathrm{Rb}^{+}$ & no mineral equivalent & rubidium jarosite & $\mathrm{RbFe}_{3}\left(\mathrm{SO}_{4}\right)_{2}(\mathrm{OH})_{6}$ \\
\hline
\end{tabular}

\section{PROPERTIES OF JAROSITE}

\subsection{Mineralogy of jarosite}

Alunite $\left(\mathrm{Al}_{3}\left(\mathrm{SO}_{4}\right)_{2}(\mathrm{OH})_{6}\right)$ relates to jarosite through similarities in structure and properties, with aluminum substituted for iron, and is often presently associated with jarosite. Jarosite has a well-defined X-ray diffraction (XRD) pattern (Figure 1), which allows for clear identification by this technique, even in low concentrations. However, XRD can sometimes not properly identify jarosite when it is a very finesized crystal or amorphous. Jarosite species have some mineralogical features that correspond to associated minerals such as pyrites and limonite $[2,13,15,16]$.

\subsection{Structure of jarosite}

Jarosites are trigonal crystals in space group $R 3 \mathrm{~m}$ and consist of sheets of hydroxy and sulfate bridged ferric ion distorted octahedra $[11,13]$. The structure of jarosite is shown in Figure 2. Parameter $a$ in the unit cell is presented as $7.3 \AA$, but it differs with synthesis conditions. Parameter $c$ ranges from 16.5 to $17.4 \AA$ for monovalent cation substitution such as ammoniojarosite and $33.7 \AA$ for divalent cation divalent substitution such as plumbojarosite.

Elemental analysis for specific cations can be used to establish the specific jarosite type (Table 2). Jarosite groups in the environment are typically mixtures solid solutions with various cationic substitutions rather than end-member compositions $[6,8]$.

Various modes of vibrations present in the jarosite structure can be explained by its IR-spectra (Figure 3) [11].

Figure 3 show that the absorption peak in the region of 2900-3700 $\mathrm{cm}^{-1}$ was ascribed to the O-H stretching; the absorption peak of $1425 \mathrm{~cm}^{-1}$ was attributed to the $\mathrm{NH}_{4}^{+}$ stretching the $\mathrm{v} 4, \mathrm{v} 3, \mathrm{v} 2$ and $\mathrm{v} 1$ vibration of $\mathrm{SO}_{4}{ }^{2-}$ were represented in the wave numbers of $628,1194,1085$, and 1004 $\mathrm{cm}^{-1}$, respectively; the vibration peaks of $\mathrm{FeO}_{6}$ were observed in the wave numbers of $511 \mathrm{~cm}^{-1}$ and $473 \mathrm{~cm}^{-1}$ [10]. According to the above result, we can conclude that the precipitates which bio-mediated are ammonium jarosites with the formula of $\mathrm{NH}_{4} \mathrm{Fe}_{3}\left(\mathrm{SO}_{4}\right)_{2}(\mathrm{OH})_{6}$.

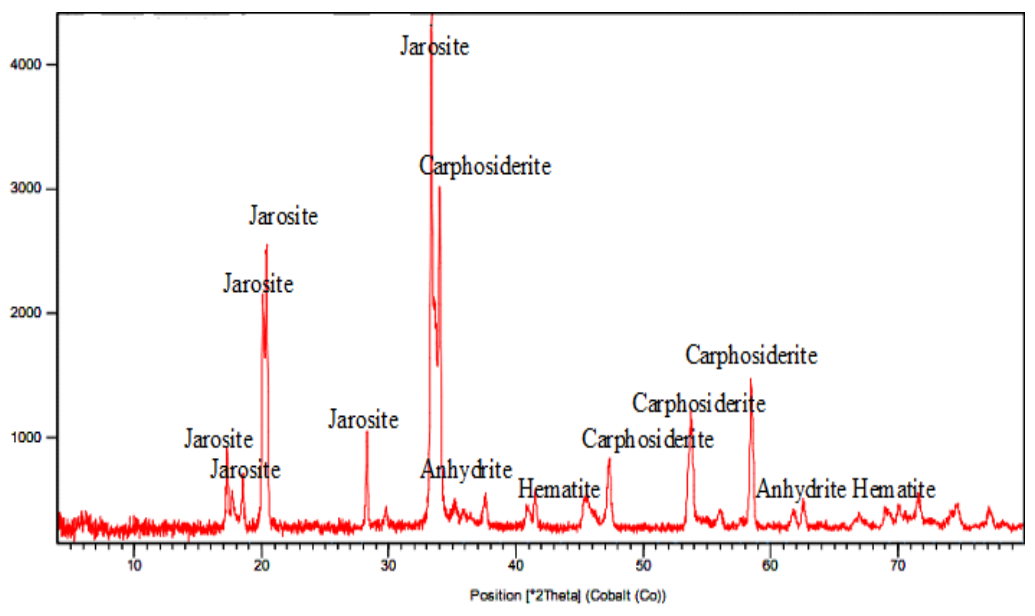

Figure 1. XRD patterns of jarosites

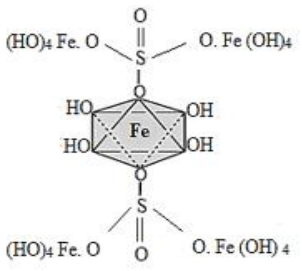

(a)

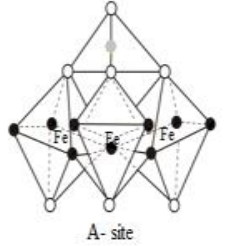

(b)

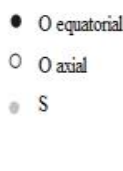

(c)

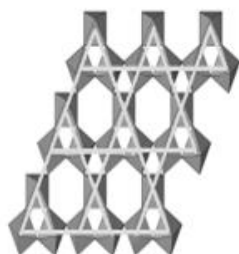

Figure 2. Structure of jarosite (a) single unit (b) crystal structure of sulfate tetrahedra and FeO6 octahedra (c) schematic of a single layer of $\mathrm{Fe}-\mathrm{O}$ coordination octahedra 
Table 2. Elemental composition of variously produced jarosites by the microbial method $[6,8]$

\begin{tabular}{cccccccc}
\hline Cations & \multicolumn{9}{c}{ Elemental composition (wt \%) } & & Mol Ratio \\
\hline & $\mathrm{K}$ & $\mathrm{Na}$ & $\mathrm{Ag}$ & $\mathrm{Fe}$ & $\mathrm{S}$ & $\mathrm{N}$ & $\mathrm{Fe} / \mathrm{S}$ \\
$\mathrm{K}^{+}$ & 7.82 & 0 & 0 & 33.5 & 12.9 & 0 & 1.5 \\
$\mathrm{NH}^{+}$ & 0 & 0 & 0 & 35.0 & 13.4 & 2.93 & 1.5 \\
$\mathrm{Na}^{+}$ & 0 & 4.74 & 0 & 34.6 & 13.3 & 0 & 1.5 \\
$\mathrm{H}^{+} \mathrm{O}^{+}$ & 0 & 0 & 0 & 34.9 & 13.4 & 0 & 1.5 \\
$\mathrm{Ag}^{+}$ & 0 & 0 & 14.6 & 29.1 & 11.2 & 0 & 1.5 \\
\hline
\end{tabular}

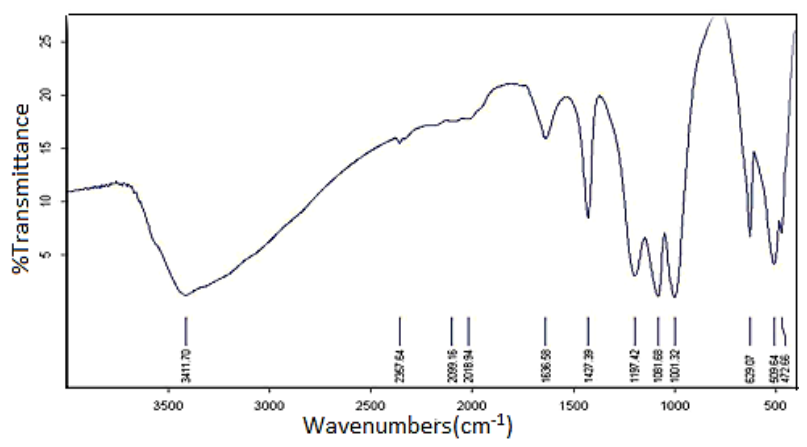

Figure 3. FTIR spectrum of jarosite

\section{SYNTHESIZE OF JAROSITE}

Methods of producing synthetic jarosite seeds consist of biological and chemical technologies. The biological method can produce synthetic jarosite seeds at room temperature whereas the chemical method was carried out at high temperature. Ivarson in 1973 was among the first to synthesize jarosite with microbial oxidation of ferrous sulfate [7]. Since then, some studies shown that jarosites can be produced from ferrous sulfate by acidophilic Fe (III)-oxidizing- bacteria such as Acidithiobacillus ferrooxidans $[6-8,10,13] . A$. ferrooxidans is a Gram negative, acidophilic, obligate chemolithoautotrophic proteobacterium which can get energy from the oxidation of ferrous iron or reduction of sulfur $\left(\mathrm{S}^{0}\right)$ compounds. It has a significant impact on the precipitation of jarosite. A. ferrooxidans usually grows in liquid 9K medium [9, 10, 16-20]. Sasaki and Konno [7] utilized A. ferrooxidans in $9 \mathrm{k}$ medium for precipitation of jarosite. They detected that the precipitate formed in the biological medium (9k) usually contained potassium jarosite or a mixture of ammonium and potassium jarosites [7].

The formation of jarosite initiates by biological oxidation of ferrous to ferric ions, followed by formation of crystal nuclei and lastly the growth of complete crystals [7]. The technique and rate of ferrous ions oxidation are known to have an effect on the appearances of the jarosite formed. In 1995 Sasaki et al. [6] reported that biological synthesis made no direct contribution to the crystallization of jarosites [6]. In 2000 Sasaki and Konno [7] showed that the jarosites synthesized by biological method had significantly different morphology compared to those produced chemically. In 2015 Liu et al. [20] used biological seeds and chemical seeds on jarosite process. Obtained results are shown in Figure 4. They observed that chemical jarosite seeds appear like a dense, stacked corolla and rough particle size. Biological jarosite was smooth, sleek and particle size less than $5 \mu \mathrm{m}$. Also, they found that the process of jarosite precipitation was more complete by biological jarosite seeds.

According to the studies of Sadowski et al. [18] the extracellular polysaccharides of bacteria has an important effect on the morphology of the jarosite particles. In addition, the crystallization parameters have effect on the physical properties, particle size and morphology of jarosite [20, 21]. Liu et al. [21] studied influences of parameters such as agitation speed, temperature, and initial concentration of ferric sulfate in a batch crystallizer. It was reported that parameters of crystallization had a great influence on the morphology (polyhedron, spherical and irregular shapes) of ammonium jarosite.

Wang et al. [19] studied the transformation of schwertmannite to jarosite using iron-oxidizing acidophilic bacteria. They observed that, jarosite and schwertmannite $\left[\mathrm{Fe}_{8} \mathrm{O}_{8}(\mathrm{OH})_{6} \mathrm{SO}_{4}\right]$ could be precipitated from ferrous sulfate mineral salt media inoculated with $A$. ferrooxidans, and elevated that temperature and higher concentrations ammonium ions led to jarosite precipitation while lower temperature and ionic concentrations precipitated schwertmannite. Besides, they observed the conversion of schwertmannite into jarosite, in the presence of monovalent ions, but the elemental composition, specific surface area and color of these "transformed jarosites" were different from those jarosites that were directly precipitated upon bacterial iron oxidation. Gramp et al. [8] synthesized and characterized different types of jarosites in liquid media inoculated with $A$. ferrooxidans and having a range $\mathrm{Na}^{+}, \mathrm{K}^{+}$, and $\mathrm{NH}_{4}^{+}$ concentrations in to determine the practical concentrations of monovalent cations required for jarosite formation. The concentration of monovalent cations required varied depending on the type of jarosite. Results showed that, natrojarosite required the highest level of the cation and potassium jarosite the lowest level.

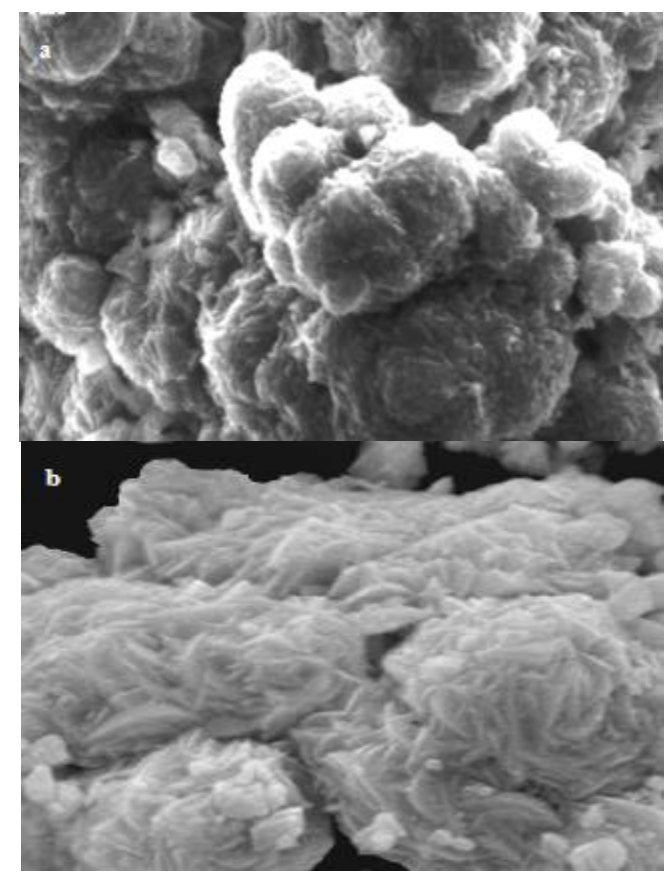

Figure 4. SEM images of morphology of jarosite seeds by different techniques: (a) Biological technique; (b) Chemical technique [20]

\section{MECHANISMS OF FORMATION}

As it mentioned, the precursors for jarosite formation are iron, sulfate, a cation source, and acidophilic Fe (III)- 
oxidizing- bacteria, in a temperature and $\mathrm{pH}$ range conducive to jarosite precipitation. The first step in the formation of iron precipitation is ferrous ion oxidation that occurring via Eq. (1).

$$
4 \mathrm{Fe}^{2+}+\mathrm{O}_{2}+4 \mathrm{H}^{+} \rightarrow 4 \mathrm{Fe}_{3}^{+}+2 \mathrm{H}_{2} \mathrm{O}
$$

Since there is a consumption of hydrogen ions, the $\mathrm{pH}$ of the broth media $(9 \mathrm{~K})$ initially increases. However, this $\mathrm{pH}$ increase is counteracted via the hydrolysis of ferric iron, as shown by Eqns. (2), (3) and (4) [22-24].

$$
\begin{gathered}
\mathrm{Fe}^{3+}+\mathrm{H}_{2} \mathrm{O} \leftrightarrow \mathrm{FeOH}^{2+}+\mathrm{H}^{+} \\
\mathrm{Fe}^{3+}+2 \mathrm{H}_{2} \mathrm{O} \leftrightarrow \mathrm{Fe}(\mathrm{OH})_{2}^{+}+\mathrm{H}^{+} \\
\mathrm{Fe}^{3+}+3 \mathrm{H}_{2} \mathrm{O} \leftrightarrow \mathrm{Fe}(\mathrm{OH})_{3}+\mathrm{H}^{+}
\end{gathered}
$$

Jensen and Webb in 1995 reported that the $\mathrm{pH}$ of the system affected the extent of the oxidation and hydrolysis reactions. Furthermore, there is a reaction in competition with the hydrolysis reaction giving products of basic ferric hydroxy sulfates [25]. These hydroxy sulfate precipitates are known as jarosites, as shown by Eq. (5).

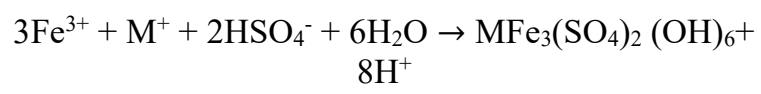

The roughly explained process of precipitation of jarosite involves three steps: oxidation of ferrous to ferric ions, the formation of crystal nuclei (embryo) and the growth of crystals of a jarosite group phase [7, 23]. According to the multi-step of jarosite nature formation, it is expected that this process is affected by several factors.

\section{FACTORS AFFECTING JAROSITE FORMATION}

Several factors play a role in the rate of biological oxidation of ferrous ions by means of $A$. ferrooxidans. These factors consist of bacterial concentration, dissolved oxygen, concentrations of ferrous/ferric iron and monovalent cations, $\mathrm{pH}$, temperature, aging time, reactor type and the molar ratio of $\mathrm{Fe} / \mathrm{K}, \mathrm{Fe} / \mathrm{NH} 4, \mathrm{Fe} / \mathrm{Na}, \mathrm{Fe} / \mathrm{H} 3 \mathrm{O}$ [9, 11, 23, 26-28].

Based on a numerical study by Daoud et al. [23] the $\mathrm{pH}$ and temperature have important effects on the biological oxidation kinetics of iron by A. ferrooxidans. The $\mathrm{pH}$ range of 1.0-3.0 is well-documented to favor jarosite formation, whereas a higher $\mathrm{pH}$ range result in the dominant formation of schwertmannite. Several studies have been conducted to find the optimum $\mathrm{pH}$ and temperature ranges for $A$. ferrooxidans operation. Some findings are as shown in Table 3 . According to Table 3 , the $\mathrm{pH}$ and temperature at which the bacterium has the highest rate of oxidation and operation are about 2.0 and $30^{\circ} \mathrm{C}$, respectively.

The jarosite formation requires the nucleation of a new phase, and this reaction will likely depend on several factors for instance seeding, and purity of the reagents. Hence, it is not surprising that wide variations have been noted for the effect of seeding. Seeding was reported by some authors to have only a slight effect $[33,34]$, however, abundant seeding was noted by others to have a major influence [20, 35-37]. Studies by Dutrizac [2] showed that seeding accelerated the rate of jarosite formation; similar effects were observed by Li et al. [20] for ammonium jarosite. The precipitation process of jarosite is more complete with seeding [20]. Studies show that bacterial immobilization and biofilm processes have an influence on jarosite formation. Pogliani and Donati [22] showed that $A$. ferrooxidans cells immobilization using glass beads as support occurred essentially on the jarosite formed in culture. They demonstrated that glass beads were very useful to set the conditions for important jarosite precipitation in biofilm formation. As mentioned, the $\mathrm{O}_{2}$ supply level is one of the factors in the biological synthesis of jarosite. Hou et al. [9] reported that the continuous supply of $\mathrm{O}_{2}$ was only important

\begin{tabular}{|c|c|c|c|}
\hline Source & $\begin{array}{c}\text { Optimum } \\
\text { pH }\end{array}$ & Source & $\begin{array}{c}\text { Optimum } \\
\text { temperature }\left({ }^{\circ} \mathrm{c}\right)\end{array}$ \\
\hline $\begin{array}{l}\text { Karamanev } \\
\text { et al. [29] }\end{array}$ & 2.0 & $\begin{array}{l}\text { Smith et al. } \\
\text { [31] }\end{array}$ & $25-30$ \\
\hline $\begin{array}{c}\text { Torma } \\
{[30]}\end{array}$ & 2.3 & $\begin{array}{c}\text { Ahonen et al. } \\
\text { [33] }\end{array}$ & 28 \\
\hline $\begin{array}{c}\text { Smith et al. } \\
\text { [31] }\end{array}$ & $2.0-2.3$ & $\begin{array}{c}\text { Okereke et al. } \\
{[34]}\end{array}$ & 30 \\
\hline $\begin{array}{l}\text { Drobner et } \\
\text { al. [32] }\end{array}$ & 2.0 & $\begin{array}{c}\text { Nemati et al. } \\
\text { [35] }\end{array}$ & 35 \\
\hline $\begin{array}{l}\text { Eftekhari } \\
\text { et al. [10] }\end{array}$ & 2.0 & $\begin{array}{c}\text { Daud et al. } \\
\text { [23] }\end{array}$ & 35 \\
\hline
\end{tabular}
in the period of the biological oxidation of ferrous iron to ferric but was not required in the period of ferric precipitation.

Table 3. The optimum $\mathrm{pH}$ and temperature ranges for $A$. ferrooxidans as reported by various sources

\section{DECOMPOSITION OF JAROSITE}

The decomposition of jarosite was first studied by Kunda and Veltman [38]. Decomposition of jarosite was reported to be carried out using two different methods: (i) thermal decomposition and (ii) hydrothermal decomposition. In both ways, jarosites decompose to the most stable phase of iron, hematite. Thermal decomposition of jarosite would take place as Eqns. (6) and (7):

$$
\begin{aligned}
& 2 \mathrm{AFe}_{3}\left(\mathrm{SO}_{4}\right)_{2}(\mathrm{OH})_{6} \rightarrow \underset{6}{ } \mathrm{~A}_{2} \mathrm{SO}_{4} \cdot \mathrm{Fe}_{2}\left(\mathrm{SO}_{4}\right)_{3}+2 \mathrm{Fe}_{2} \mathrm{O}_{3}+ \\
& \mathrm{A}_{2} \mathrm{SO}_{4} \cdot \mathrm{Fe}_{2}\left(\mathrm{SO}_{4}\right)_{3} \rightarrow \mathrm{A}_{2} \mathrm{SO}_{4}+\mathrm{Fe}_{2} \mathrm{O}_{3}+3 \mathrm{SO}_{3}
\end{aligned}
$$

Hydrothermal decomposition can be performed in two different ways: (i) alkali decomposition and (ii) acid decomposition [13]. The alkaline hydrothermal decomposition may be the most appropriate pre-treatment process to recover the silver by cyanidation since both processes (cyanidation and decomposition) are carried out by similar alkaline $\mathrm{pH}$ value. The hydrothermal decomposition of argentojarosite in alkaline media and its effect on cyanidation have been investigated by a number of researchers. They determined that the alkaline decomposition of synthetic argentojarosite is characterized via the elimination of sulfate ions from the lattice and the formation of a gel type compound consisting of silver hydroxides and iron, as shown by Eq. (8) [13, 37, 39].

$$
\begin{aligned}
\mathrm{AgFe}_{3}\left(\mathrm{SO}_{4}\right)_{2}(\mathrm{OH})_{6}+ & 4 \mathrm{OH}^{-} \rightarrow \mathrm{Ag}(\mathrm{OH})+3 \mathrm{Fe}(\mathrm{OH})_{3} \\
& +2 \mathrm{SO}^{2-}
\end{aligned}
$$

The dissolution of calcium hydroxide $\left(\mathrm{Ca}(\mathrm{OH})_{2}\right)$ or sodium hydroxide $(\mathrm{NaOH})$ provides hydroxyl ions, which allows the formation of silver hydroxide, iron hydroxide (III) and sulfate 
ion in solution. The impact of $\mathrm{Ca}(\mathrm{OH})_{2}$ and $\mathrm{NaOH}$ in hydrothermal decomposition of the deposited industrial jarosite have been investigated by González-Ibarra et al. [39]. The results of their investigation indicated that the $\mathrm{pH}$ value had an important effect on the hydrothermal decomposition when either $\mathrm{Ca}(\mathrm{OH})_{2}$ or $\mathrm{NaOH}$ was added to control $\mathrm{pH}$ value. The results showed that when $\mathrm{NaOH}$ was applied, the process kinetics were controlled by the chemical reaction and when $\mathrm{Ca}$ $(\mathrm{OH})_{2}$ was used, the rate-determining step was transformed to a diffusion control through the solid product layer.

\subsection{Biological dissolution}

Microbial dissolution of jarosites is a green and eco-friendly in nature. Some bacteria such as Shewanella putrefaciens CN32, Geobacter metalloproteins are able to use Fe (III)bearing minerals as an electron acceptor. The products of this reduction can have an influence on the mobilization or sequestration of inorganic and organic pollutants [40, 41].

In 2000, Bridge and Johnson [42] studied dissolution of jarosite by IRB [iron-reducing bacteria] in acidic $(\mathrm{pH}<2.5)$ conditions [42]. Experimental evidence indicates that at low $\mathrm{pH}$, Acidiphilium $\mathrm{SJH}$ can accelerate the dissolution of jarosite by way of an indirect mechanism, in which bacterial reduction of dissolved ferric ion results in a shift in equilibrium between solid -phase Fe (III) and dissolved ferric ion, thereby driving dissolution of the mineral phase [42-44].

Jarosite dissolution at low $\mathrm{pH}$ is an effective method for jarosite removal. Madden et al. [45] found that the potassium jarosite dissolution rates increased at both low and high $\mathrm{pH}$ ( $\mathrm{pH}$ ranges from 1 to 11 ) with minimum dissolution rates observed at $\mathrm{pH}$ 3.5. At $\mathrm{pH}<3.5$, the dissolution rate of potassium jarosite increased as the activity of $\mathrm{H}^{+}$in the system increased and no secondary reaction products were produced during the process.

Sulfate-reducing bacteria (SRB) such as Sulfobacillus thermosulfidooxidans, Sulfobacillus acidophilus, Desulfosporosinus orientis are named from their capacity to use sulfate as a terminal electron acceptor and are notable in many acidic environments including AMD. SRB prefer lowmolecular-weight forms of organic carbon such as lactate, and gain energy from the electron transfer between organic compounds and electron acceptors with the reduction of sulfate to sulfide. Besides the indirect reduction of iron oxide through the production of sulfide, some known SRB are capable of reducing $\mathrm{Fe}^{3+}$ via an enzymatic mechanism. Theoretically, both the $\mathrm{SO}_{4}{ }^{2-}$ and $\mathrm{Fe}^{3+}$ in jarosite have the potential to serve as terminal electron acceptors for SRB [42, $44,45]$.

In 2018 Bao et al. [46] examined the reductive dissolution of jarosite by a mixed microbial community containing SRB and observed that SRB could facilitate the transformation of jarosite to goethite. Although these studies show that jarosite can be utilized as an electron acceptor by SRB, the mechanism involved has yet to be elucidated.

In 2019 Gao et al. [47] studied the mechanism of the microbial reduction of jarosite by an indigenous SRB community. and reported that the reduction of jarosite by SRB occurred via an indirect mechanism.

In 2019 Yang et al. [48] examined the ability of $A$. ferrooxidans to bio- dissolve jarosites by anaerobic reduction using hydrogen as an electron donor and observed that jarosite could dissolution in anaerobic condition. During biodissolution, the mechanisms underlying the anaerobic bio- dissolution of jarosites by $A$. ferrooxidans included direct contact bio-dissolution and indirect bio-dissolution and were associated with the solubility of jarosites.

According to the investigations of Catro et al. [49], bacterial attachment and biofilm formation of minerals have a great impact on the production and transformation of minerals and can influence the mobility of metals. Some of investigations with SRB biofilms have shown that the decrease and precipitation of metal sulphides occur inside the biofilm matrix. These biofilms are formed by aggregations of one or more types of microorganisms that are embedded in a selfproduced matrix of EPSs [extracellular polymeric substances], that can grow on many different surfaces, such as mineral surfaces.

\section{APPLICATIONS OF JAROSITE}

With the jarosite group of compounds representing a problem, many studies have been completed to extract economic benefit from products associated with its production.

Jarosite synthesized by biological technology has been used for yellow pigments, building materials, Iron and arsenic removal, adsorption materials, catalytic materials [20, 50-56], because of its distinctive performance. However, the most significant interest in jarosite arises from a hydrometallurgical perspective. The applications of jarosite are shown in Figure 5. Applications of jarosite precipitation are briefly discussed below:

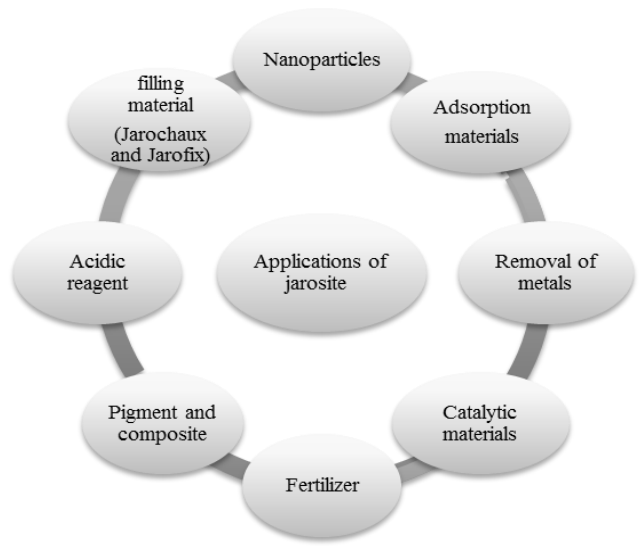

Figure 5. Flow sheet applications of jarosite

\subsection{Nanoparticles}

In many studies, Argentojarosite has been considered as the source of silver [44, 57]. Weisener et al. [44] investigated the influences of Shewanella putrefaciens CN32 on silver (Ag-)jarosite under reducing conditions at circumneutral $\mathrm{pH}$. They observed that the silver nanoparticles were formed during the dissolution of argentojarosite. Silver as a catalyst has been shown to have a considerable effect on improving the rate of chalcopyrite bioleaching. New advances in Agnanoparticle research have led to their growing use in clinical and engineering applications [50].

\subsection{Removal of iron as jarosite for solution purification}

\subsubsection{Zn-Fe solutions}

One of the most important applications of jarosite is the iron removal from acidic solutions in hydrometallurgical process. 


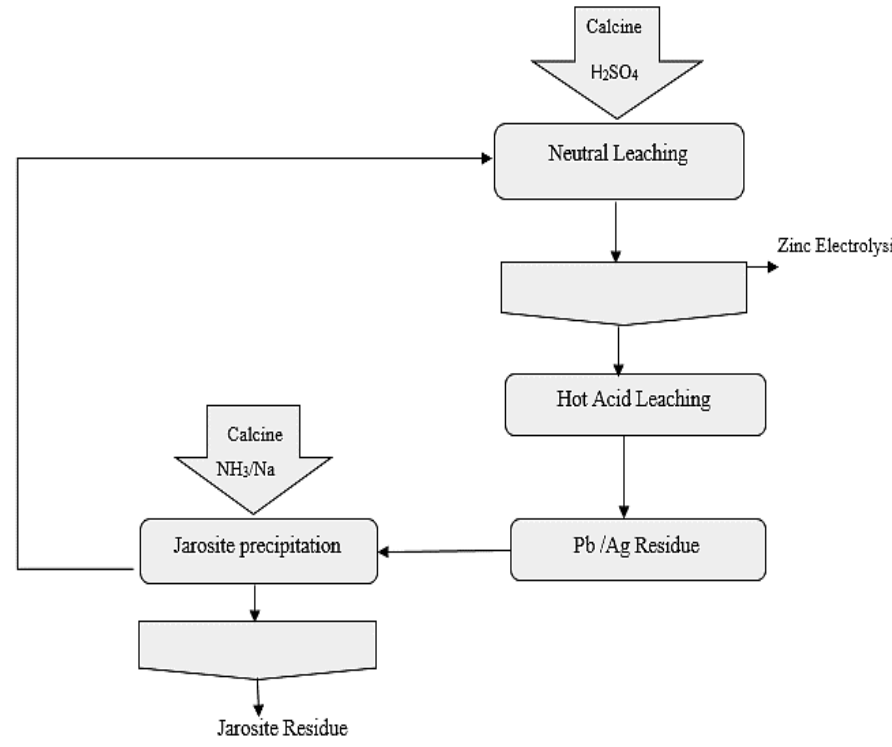

Figure 6. Flow sheet incorporation of jarosite precipitation circuit in zinc extraction

As shown in Figure 6 in zinc industry, the jarosite process is used to precipitate iron from hot acid leach solutions in the processing circuit after addition of alkali ions $\left(\mathrm{NH}_{3}, \mathrm{Na}_{2} \mathrm{CO}_{3}\right.$ or $\mathrm{Na}_{2} \mathrm{SO}_{4}$ ) [2]. The neutralizing agent is usually calcined and is required to control both the residual acidity from the hot acid leach and the acid produced by the hydrolysis of the ferric ions
[58]. In the $\mathrm{Zn}-\mathrm{Fe}$ solutions the precipitation reaction is greatly accelerated by the presence of jarosite seed, and the rate increase with increasing seed addition [14].

\subsubsection{Ni-Co-Fe solutions}

Removal of iron as jarosite has been investigated by several studies from Ni- Co- Fe sulphate solution resulting from the laterite leaching. Precipitation has been carried out at a constant $\mathrm{pH}$ using $\mathrm{CaCo}_{3}$ or $\mathrm{Li}_{2} \mathrm{Co}_{3}$ as the neutralizing agent. Small amounts of nickel and cobalt co-precipitation and association of hydronium jarosite were observed [2].

\subsubsection{Iron removal as jarosite during leaching}

Iron is generally present in leach and bioleaching solutions and its elimination is a major operational problem in hydrometallurgy $[58,59]$. The recovery of iron from copper leach solutions is usually carried out by precipitation as jarosite (Figure 7). This compound is commonly applied in the zinc industry to eliminate iron solubilized in the processing circuit, as shown by Eq. (9). In this process, iron is precipitated from the hot acid leaching solution at elevated temperatures $\left(95-97^{\circ} \mathrm{C}\right)$ in the presence of sodium or ammonium ions $[2,58,60]$.

$$
\begin{gathered}
3 \mathrm{ZnO} . \mathrm{Fe}_{2} \mathrm{O}_{3}+\mathrm{A}_{2} \mathrm{SO}_{4}+6 \mathrm{H}_{2} \mathrm{SO}_{4} \\
\mathrm{ZnSO}_{4}+2 \mathrm{AFe}_{3}\left(\mathrm{SO}_{4}\right)_{2}(\mathrm{OH})_{6}
\end{gathered}
$$

With an increase in temperature $\mathrm{SO}_{4}{ }^{2-}$ and $\mathrm{NH}_{4}{ }^{+}$ions concentration the conversion rate of jarosite increase but $\mathrm{Zn}^{2+}$ ions tend to rate the conversion rate $[58,60]$.

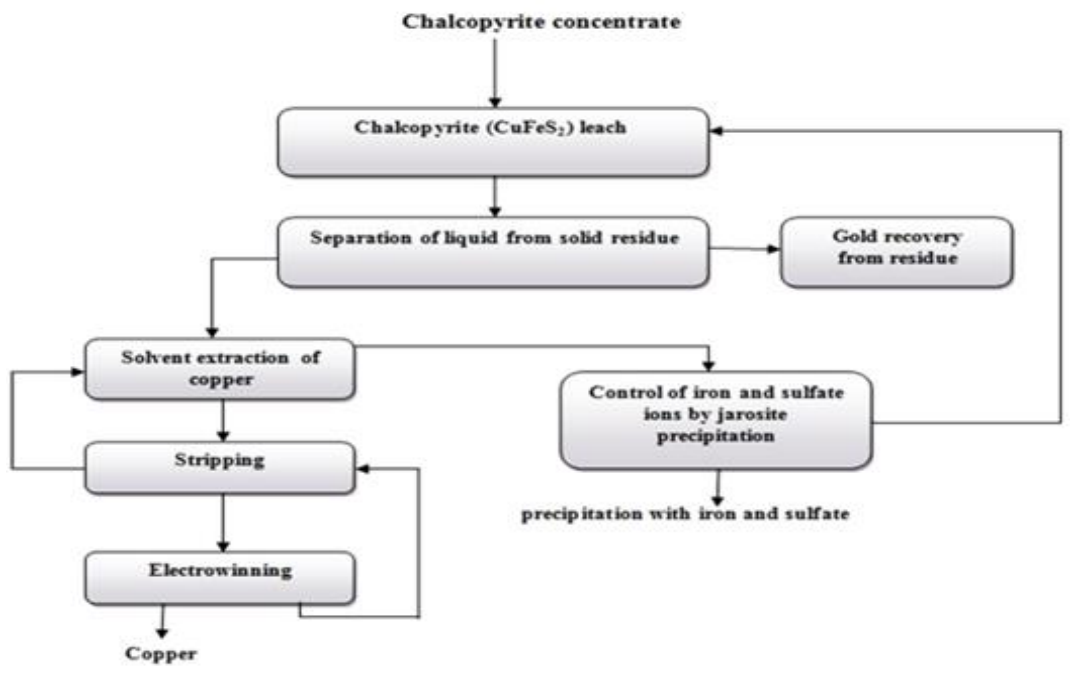

Figure 7. Flow sheet process of iron removal in copper extraction

\subsection{Catalytic materials}

The technique of adding jarosite seed is widely used to accelerate precipitation rate and shorten the induction period $[37,58]$. The relationship between the quantity of seed and the rate of jarosite precipitation is of great importance. Dutrizac [36] studied the influence of seeding on the rate of precipitation of sodium jarosite and ammonium jarosite and found that the seeds can reduce the reliance of the jarosite process on $\mathrm{pH}$ and temperature.

In $2015 \mathrm{Li}$ et al. [20] investigated the catalytic performance of seeds on jarosite formation. The induction time was reduced to $20 \mathrm{~min}$, and the reaction rate was improved noticeably, up to $3.933 \% / \mathrm{min}$. In addition, the crystallinity of the jarosite product by means of biological seeds could achieve $97.22 \%$, whereas it was only $12.89 \%$ without seeds. Their results indicated that using biological seed could enhance the catalytic performance of jarosite formation. Compared with chemical seeds, biological seeds could shorten the induction period, weaken dependence on temperature, and reduce the temperature limit in the jarosite process.

\subsection{Jarosite as fertilizer}

The potassium jarosite was discovered for the first time at Gumma limonite mine by Katayama and Saito in 1947. Various treatments of this mineral for fertilizer were devised and among them, the processes that manufactured the 
industrial products were the calcination method by Katayama, the dry decomposition technique via ammonium by Suzuki and the wet ammonium process by Ota [61]. All these products had a water-soluble potassium and the fertilizer value was the same as that of potassium sulfate. Potassium jarosite is insoluble in water and it is supposed that it has no potassic effect for fertilizer.

According to some studies, the jarosite if free from heavy metals can be converted to fertilizer, iron-sulfur by $\mathrm{H}_{2} \mathrm{SO}_{4-}$ $\mathrm{NH}_{3}$ treatment for utilization of its $\mathrm{NH}_{4}^{+}, \mathrm{K}^{+}, \mathrm{Fe}^{3+}$, and $\mathrm{SO}_{4}{ }^{2-}$. Iron-sulfur was reported to have been produced from the clear process and commercially marketed $[2,13,59]$.

\subsection{Jarosite as a pigment and composite}

Jarosites have a characteristic amber yellow or dark brown color [16]. The solution phase concentration of the monovalent cation has a significant effect on the jarosite color. This characteristic of jarosite indicates that jarosite can be used in pigments, building materials like bricks, blocks, cement, tiles, and composites [13]. In $2010 \mathrm{Vu}$ et al. [52] investigated the approaches for the production of pigment quality magnetite from jarosite, which were precipitated from manganese sulfate leach liquors. They observed that the ammonium and sodium jarosite produced from the acidic leaching solution was transformed into pigment-quality magnetite by alkali decomposition of jarosite using ammonia or sodium hydroxide

\subsection{Jarosites as potential acid generators}

Acid can be produced by mineral wastes because of the sulfide-mineral oxidation, the dissolution of less soluble sulfate minerals, for instance jarosite group minerals and the dissolution of soluble sulfate salts [62, 63]. Hydroniumbearing jarosite, in particular, is thought to contribute to acid generation in mining wastes. Jarosite precipitates are usually associated with acid-sulfate soils and acid-producing mineral waste. Because of their association with acidic conditions, jarosite minerals can be used as a proxy in remote sensing studies to locate areas of high acidity [62]. The role of jarosite precipitations as potential sources of acid has been a controversial subject. In 2008 Welch et al. [64] and references therein described that jarosite precipitations can be a major source of acidity in some Australian coastal soils. According to Welch's study [64], acid is produced by the following reaction during jarosite dissolution.

$$
\begin{aligned}
\mathrm{KFe}_{3}\left(\mathrm{SO}_{4}\right)_{2}(\mathrm{OH})_{6} \rightarrow & 3 \mathrm{FeO}(\mathrm{OH})+\mathrm{K}^{+}+2 \mathrm{SO}^{2-} \\
& +3 \mathrm{H}^{+}
\end{aligned}
$$

Jarosite and visible light are important factors for the formation of acid. In 2020 Yang et al. [63] indicated that jarosite and visible light could significantly accelerate chalcopyrite bio-dissolution, thus releasing more copper ions, iron ions and producing more acid.

\subsection{Jarosite as filling material (Jarochaux and Jarofix)}

One of the applications tested possible utilization of jarosite is to covert its sulfate to gypsum $\left(\mathrm{CaSO}_{4} \cdot 2 \mathrm{H}_{2} \mathrm{O}\right)$ by neutralizing and solidifying with $20 \%$ excess $\mathrm{CaO}$. The process is known as a jarochaux process [13]. Jarofix is a stabile material obtained by mixing jarosite with $10 \%$ Portland cement and $2 \%$ lime. It has the potential to be applied for the construction of road embankment. While jarofix-soil mix (50$75 \%)$ and jarofix- bottom ash mix $(50-75 \%)$ have the potential to be utilized for the construction of embankment and may be used for construction of subgrade layer of road pavement. For minimization of leaching of heavy metals, Hindustan Zinc Ltd. (HZL) in India is presently treating jarosite with Jarofix [60, 65].

\section{DISADVANTAGES OF JAROSITE PRECIPITATION}

Despite its widespread application, the jarosite process is not without its problems, especially in the hydrometallurgy processes. Some of the effects include the diminishment of ferric iron used as the absorbent for hydrogen disulfide, blockage of pumps, valves, pipes, corrosion process, and the creation of kinetic barriers due to the small diffusion of reactants and products through the precipitation zone [10, 22, 63-67]. In the process of coal desulfurization, jarosite attaching on the surface of the bio-oxidized coal particles results in a compact thin layer of membrane, which may hinder the transfer of substrates and metabolites and decrease bacterial absorbability of nutrients; it can also occupy the available sites of coal surfaces to prevent bacteria from adsorption on coals. Furthermore, it results in residual sulfur, which cannot be removed from coal $[6,22]$. However, biological jarosites have advantages in other industries, most of which are cost-effective.

\section{CONCLUSIONS}

Our review indicates several worthy avenues of research to improve the processing of jarosite in the future.

(1) Jarosite precipitation method is most widely used in hydrometallurgical processes mainly to control iron in the solution purification step. However, the dynamics of this process are slow, and the induction period in the initial stage is long.

(2) Leaching bacteria (Acidithiobacillus ferrooxidans) are successfully applied to synthesizing jarosite seeds with higher crystallinity. Compared with chemical jarosite seeds, biological jarosite seeds can shorten the induction period and reduce the temperature limit in the jarosite precipitation. The precipitation process of jarosite is more complete with biological jarosite seeds. The crystallization parameters such as $\mathrm{Fe}_{2}\left(\mathrm{SO}_{4}\right)_{3}$ concentration, agitation speed, $\mathrm{pH}$ and temperature have significantly affected on the morphology and the particles size of jarosite.

(3) Jarosites are known to be commonly prepared at $\mathrm{pH} 2$ and $30-35^{\circ} \mathrm{C}$. The rate of the reaction increases with temperature and seeding eliminates the initial induction period.

(4) Jarosite seed is a potential resource that needs to be recycled in a technically feasible and environmentally friendly method. Therefore, converting hazardous jarosite into a nonhazardous material is of great importance. Though some research is done in this direction, a suitable economic evaluation would be required. Many alternate applications of jarosites such as iron removal, filling materials, nanoparticles, and pigment have been suggested. From an economic standpoint, the use of these newly developed materials can be very attractive in many of the aforementioned applications because they are composed only of cheap (or free) industrial wastes. 


\section{ACKNOWLEDGMENTS}

This research was supported by the National Iranian Copper Industries Company (NICICO).

\section{REFERENCES}

[1] Swayze, G.A., Desborough, G.A., Smith, K.S., Lowers, H.A., Hammarstrom, J.M., Diehl, S.F., Leinz, R.W., Driscoll, R.L. (2008). Understanding jarosite from mine waste to Mars. In: Verplanck, P.L. (eds) in Understanding Contaminants Associated with Mineral Deposits. Geological Survey Circular, USA.

[2] Dutrizac, J.E., Jambor, J.L. (2000). Jarosites and their application in hydrometallurgy. Reviews in Mineralogy and Geochemistry, 40: 405-452. https://doi.org/10.2138/rmg.2000.40.8

[3] Dutrizac, J.E. (2008). Factors affecting the precipitation of potassium jarosite in sulfate and chloride media. Metallurgical Transactions B: Process Metallurgy, 39(6): 771-783. https://doi.org/10.1007/s11663-008-9198-7

[4] Kotler, J.M., Hinman, N.W., Yan, B., Stoner, D.L., Scott, J.R. (2008). Glycine identification in natural jarosites using laser desorption fourier transform mass spectrometry: Implications for the search for life on mars. Astrobiology, 8(2): 253-266. https://doi.org/10.1089/ast.2006.0102

[5] Ivarson, K.C., Ross, G.J., Miles, N.M. (1979). The microbiological formation of basic ferric sulfates: II. Crystallization in presence of potassium, ammonium, and sodium salts. Soil Science Society of America Journal, 43:

908912

https://doi.org/10.2136/sssaj1979.036159950043000500 $18 \mathrm{x}$

[6] Sasaki, K., Tsunekawa, M., Konno, H. (1995). Characterization of argentojarosite formed from biologically oxidized $\mathrm{Fe}^{3+}$ ions. The Canadian Mineralogist, 33: 1311-1319.

[7] Sasaki. K., Konno, H. (2000). Morphology of jarosite group compounds precipitated from biologically and chemically oxidized Fe ions. The Canadian Mineralogist, 38: 45-56. https://doi.org/10.2113/gscanmin.38.1.45

[8] Gramp, J.P., Jones, F.S., Bigham, J.M., Tuovinen. O.H. (2008). Monovalent cation concentrations determine the types of $\mathrm{Fe}$ (III) hydroxysulfate precipitates formed in bioleach solutions. Hydrometallurgy, 94: 29-33. https://doi.org/10.1016/j.hydromet.2008.05.019

[9] Hou, Q., Fang, D., Liang, J., Zhou, L. (2015). Significance of oxygen supply in jarosite biosynthesis promoted by Acidithiobacillus ferrooxidans. Plos One, 10(3):

$1-12$. https://doi.org/10.1371/journal.pone.0120966

[10] Eftekhari, N., Kargar, M. (2018). Assessment of optimal iron concentration in the precipitation of jarosite and the activity of Acidithiobacillus ferrooxidans. Modares Journal of Biotechnology, 9(4): 525-529.

[11] Basciano, L.C., Peterson, R.C. (2007). The crystal structure of ammoniojarosite, (NH4) Fe3(SO4) W(OH)6 and the crystal chemistry of the ammoniojarositehydronium jarosite solid-solution series. Mineralogical Magazine, $\quad 71(4)$ : 427-441. https://doi.org/10.1180/minmag.2007.071.4.427

[12] Bigham, J.M., Jones, F.S., Özkaya, B., Sahinkaya, E.,
Puhakka, J.A., Tuovinen, O.H. (2010). Characterization of jarosites produced by chemical synthesis over a temperature gradient from 2 to $40{ }^{\circ} \mathrm{C}$. International Journal of Mineral Processing, 94: 121-128. https://doi.org/10.1016/j.minpro.2010.01.005

[13] Das, G.K., Acharya. S., Anand, S., Das, R.P. (1996). Jarosite: A review. Min Pro Ext Met Rev, 16: 158-210. https://doi.org/10.1080/08827509708914135

[14] Han, H., Sun, W., Hu, Y., Jia, B., Tang, H. (2014). Anglesite and silver recovery from jarosite residues through roasting and sulfidization-flotation in zinc hydrometallurgy. Journal of Hazardous Materials, 278: 49-54. https://doi.org/10.1016/j.jhazmat.2014.05.091

[15] Najorka, J., Lewis, J.M.T., Spratt, J., Sephton, M.A. (2016). Single-crystal X-ray diffraction study of synthetic sodium-hydronium jarosite. Physics and Chemistry of Minerals, 43: 377-386. https://doi.org/10.1007/s00269-016-0802-0

[16] Liu, J.Y., Xiu, X.X., Cai, P. (2009). Study of formation of jarosite mediated by Thiobacillus ferrooxidans in $9 \mathrm{~K}$ medium. Procedia Earth and Planetary Science, 1(1): 706-712. https://doi.org/10.1016/j.proeps.2009.09.111

[17] Ivarson, K.C. (1973). Microbiological formation of basic ferric sulfates. Canadian Journal of Soil Science, 53: 315323. https://doi.org/10.4141/cjss73-046

[18] Sadowski, Z. (1999). Adhesion of microorganism cells and jarosite particles on the mineral surface. Process Metallurgy, 9: 393-398. https://doi.org/10.1016/s15724409(99)80129-1

[19] Wang, H., Bigham, J.M., Tuovinenm, O.H. (2006). Formation of schwertmannite and its transformation to jarosite in the presence of acidophilic iron-oxidizing microorganisms. Materials Science and Engineering: C, 26: 588-592. https://doi.org/10.1016/j.msec.2005.04.009

[20] Li, H.J., Yang, H.Y., Chen, G.B. (2016). Catalytic performance of biological method seeds on jarosite process. Transactions of Nonferrous Metals Society of China, 26: 557-564. https://doi.org/10.1016/S10036326(16)64144-4

[21] Liu, P.F., Zhang, Y.F. (2019). Crystallization of ammonium jarosite from ammonium ferric sulfate solutions. $\quad$ Hydrometallurgy, 189: 1-8. https://doi.org/10.1016/j.hydromet.2019.105133

[22] Pogliani, C., Donati, E. (2000). Immobilisation of Thiobacillus ferrooxidans: Importance of jarosite precipitation. Process Biochemistry, 35(9): 997-1004. https://doi.org/10.1016/S0032-9592(00)00135-7

[23] Daoud, J., Karamanev, D. (2006). Formation of jarosite during $\mathrm{Fe} 2+$ oxidation by Acidithiobacillus ferrooxidans. Minerals $\quad$ Engineering, 19: 960-967. https://doi.org/ .1016/j.mineng.2005.10.024

[24] Liu, J.S., Li, B.M., Zhong, D.Y., Xia, L.X., Qiu, G.Z. (2007). Preparation of jarosite by Acidithiobacillus ferrooxidans oxidation. Central South University of Technology, 5: 623-628. https://doi.org/10.1007/s11771-007-0119-8

[25] Jensen, A.B., Webb, C. (1995). Ferrous sulfate oxidation using Thiobacillus ferrooxidans: A review. Process Biochem, 30(3): 225-236. https://doi.org/10.1016/00329592(95)85003-1

[26] Zhu, J.Y., Gan, M., Zhang, D., Hu, Y.H., Chai, L.Y. (2013). The nature of Schwertmannite and Jarosite mediated by two strains of acidithiobacillus ferrooxidans with different ferrous oxidation ability. Materials 
Science and Engineering: C, 33: 2679-2685. https://doi.org/10.1016/j.msec.2013.02.026

[27] Herbert, R.B. (1995). Precipitation of Fe oxyhydroxides and jarosite from acidic groundwater. GFF, 117: 81-85. https://doi.org/10.1080/11035899509546203

[28] Bigham, J.M., Carlson, L., Mura, D.E. (1994). Schwertmannite, a new oxyhydroxysulphate from Pyhäsalmi, Finland, and other localities. Mineralogical Magazine, 58(393): 641-648. https://doi.org/https://doi.org/10.1180/minmag.1994.05 8.393.14

[29] Karamanev, D.G., Nikolov, L.N. (1988). Influence of some physicochemical parameters on bacterial activity of biofilm: Ferrous iron oxidation by Thiobacillus ferrooxidans. Biotechnology and Bioengineering, 31(4): 295-299. https://doi.org/10.1002/bit.260310403

[30] Torma, A.E. (1977). The role of Thiobacillus ferrooxidans in hydrometallurgical processes. Advances in Biochemical Engineering, 6: 1-37.

[31] Smith, J.R., Luthy, R.G., Middleton, A.C. (1988). Microbial ferrous iron oxidation in acidic solution. Journal Water Pollution Control Federation, 60(4): 518 530. https://www.jstor.org/stable/25043528

[32] Drobner, E., Huber, H., Stetter, K.O. (1990). Thiobacillus ferrooxidans a facultative hydrogen oxidizer. Applied and Environmental Microbiology, 56(9): 2922-2923.

[33] Ahonen, L., Tuovinen, O.H. (1989). Microbiological oxidation of ferrous iron at low temperatures. Applied and Environmental Microbiology, 55(2): 312-316.

[34] Okereke, A., Stevens, S.E. (1991). Kinetics of iron oxidation by thiobacillus ferrooxidans. Applied and Environmental Microbiology, 57(4): 1052-1056.

[35] Nemati, M., Harrison, S.T.L., Hansford, G.S., Webb, C. (1998). Biological oxidation of ferrous sulfate by Thiobacillus ferrooxidans: A review on the kinetic aspects. Biochemical Engineering Journal, 1(3): 171-190. https://doi.org/10.1016/S1369-703X(98)00006-0

[36] Dutrizac, J.E. (1996). The effect of seeding on the rate of precipitation of ammonium jarosite and sodium jarosite. Hydrometallurgy, 42: 293-312. https://doi.org/10.1016/0304-386X(95)00111-S

[37] Dutrizac, J.E. (2010). Comparative rates of precipitation of ammonium jarosite and sodium jarosite in ferric sulphate-sulphuric acid media. Canadian Metallurgical, 49(2):

$121-130$ https://doi.org/10.1179/cmq.2010.49.2.121

[38] Kunda, W., Veltman, H. (1979). Decomposition of jarosite. Metallurgical Transactions B, 10(3): 439-446. https://doi.org/10.1007/BF02652517

[39] González-Ibarra, A.A., Nava-Alonso, F., FuentesAceituno, J.C., Uribe-Salas, A. (2016). Hydrothermal decomposition of industrial jarosite in alkaline media: The rate determining step of the process kinetics. Journal of Mining and Metallurgy B: Metallurgy, 52(2): 135-142. https://doi.org/10.2298/JMMB150430016G

[40] Roca, A., Patiño, F., Viñals, J., Nuñez, C. (1993). Alkaline decomposition-cyanidation kinetics of argentojarosite. Hydrometallurgy, 33(3): 341-357. https://doi.org/10.1016/0304-386X (93)90071-K

[41] Johnson, D.B. (2012). Reductive dissolution of minerals and selective recovery of metals using acidophilic iron and sulfate reducing acidophiles. Hydrometallurgy, 128: 172-177. https://doi.org/10.1016/j.hydromet.2012.07.015

[42] Bridge, T.A.M., Johnson, D.B. (2000). Reductive dissolution of ferric iron minerals by Acidiphilium SJH. Geomicrobiology Journal, 17(3): 193-206. https://doi.org/10.1080/01490450050121161

[43] Jones, E.J.P., Nadeau, T.L., Voytek, M.A., Landa, E.R. (2006). Role of microbial iron reduction in the dissolution of iron hydroxysulfate minerals. Journal of Geophysical Research, 111: 1-8. https://doi.org/10.1029/2005JG000089

[44] Weisenera, C.G., Babechuka, M.G., Fryera, B.J., Maunder, C. (2008). Microbial dissolution of silver jarosite: examining its trace metal behaviour in reduced environments. Geomicrobiology Journal, 25: 415-424. https://doi.org/10.1080/01490450802403073

[45] Man, J.K., Boyanov, M.I., Antonopoulos, D.A., Brulc, J.M., Johnston, E.R., Skinner, K.A., Kemner, K.M., O'Loughlin, E.J. ( 2014). Effects of dissimilatory sulfate reduction on Fe III (hydr) oxide reduction and microbial community development. Geochimica et Cosmochimica Acta, 129: 177-190. https://doi.org/10.1016/j.gca.2013.09.037

[46] Bao, Y., Guo, C., Lu, G., Yi, X., Wang, H., Dang, Z. (2018). Role of microbial activity in $\mathrm{Fe}(\mathrm{III})$ hydroxysulfate mineral transformations in an acid mine drainage-impacted site from the Dabaoshan mine. Science of the Total Environment, 616-617: 647-657. https://doi.org/10.1016/j.scitotenv.2017.10.273

[47] Gao, K., Jiang, M., Guo, C.L., Zeng, Y., Fan, C., Zhang, J., Reinfelder, J.R., Huang, W., Lu, G., Dang, Z. (2019). Reductive dissolution of jarosite by a sulfate reducing bacterial community: Secondary mineralization and microflora development. Science of the Total Environment, 690: 1100-1109. https://doi.org/10.1016/j.scitotenv.2019.06.483

[48] Yang, Y.K., Chen, S., Yang, D.S., Zhang, W., Wang, H.J., Zeng, R.J. (2019). Anaerobic reductive biodissolution of jarosites by Acidithiobacillus ferrooxidans using hydrogen as electron donor. Science of the Total Environment, 686: 869-877. https://doi.org/10.1016/j.scitotenv.2019.06.071

[49] Castro, L., Blázquez, M.L., González, F., Muñoz, J.A., Ballester, A. (2019). Anaerobic bioreduction of jarosites and biofilm formation by a natural microbial consortium. Minerals, $9(81)$ : 1-14. https://doi.org/10.3390/min9020081

[50] Neu, T.R., Lawrence, J.R. (2010). Chapter 37extracellular polymeric substances in micro-bial biofilms. In: Otto, H., Patrick, J.B., Mark von Itzstein, P.J.B., Holst, O., Mark von, I. (Eds.), Microbial Glycobiology. Academic Press, San Diego.

[51] Asokan, P., Saxena, M., Asolekar, S.R. (2006). Hazardous jarosite use in developing non-hazardous product for engineering application. Journal of Hazardous Materials, 137(3): 1589-1599. https://doi.org/10.1016/j.jhazmat.2006.04.054

[52] Vu, H., Jandová, J., Hron, T. (2010). Recovery of pigment-quality magnetite from jarosite precipitates. Hydrometallurgy, $101(1-2)$ : 1-6. https://doi.org/10.1016/j.hydromet.2009.10.007

[53] Dutrizac, J.E., Chen, T.T. (2010). The behavior of phosphate during jarosite precipitation. Hydrometallurgy, 102: $55-65$. https://doi.org/10.1016/j.hydromet.2010.02.004

[54] Xu, Z., Liang, J., Zhou. L. (2013). Photo-fenton-like 
degradation of azo dye methyl orange using synthetic ammonium and hydronium jarosite. Journal of Alloys and Compounds, 546 :

112-118. https://doi.org/10.1016/j.jallcom.2012.08.087

[55] Asokan, P., Saxena, M., Asolekar, S.R. (2010). Recycling hazardous jarosite waste using coal combustion residues. Materials Characterization, 61(12): 1342-1355. https://doi.org/10.1016/j.matchar.2010.09.005

[56] Meng, X., Zhang, C., Zhuang, J., Zheng, G., Zhou, L. (2020). Assessment of schwertmannite, jarosite and goethite as adsorbents for efficient adsorption of phenanthrene in water and the regeneration of spent adsorbents by heterogeneous fenton-like reaction. Chemosphere, 244: 1-9. https://doi.org/10.1016/j.chemosphere.2019.125523

[57] Kashefi, K., Tor, J.M, Nevin, K.P, Lovley, D.R. (2001). Reductive precipitation of gold by dissimilatory Fe (III)reducing bacteria and archaea. Applied and Environmental Microbiology, 67(7): 3275-3279. https://doi.org/10.1128/AEM.67.7.3275-3279.2001

[58] Dutrizac, J.E. (1999). The effectiveness of jarosite species for precipitating sodium jarosite. Jom, 51(12): 30-32. https://doi.org/10.1007/s11837-999-0168-6

[59] Ismael, M.R.C., Carvalho, J.M.R. (2003). Iron recovery from sulphate leach liquors in zinc hydrometallurgy. Minerals $\quad$ Engineering, 16(1): 31-39. https://doi.org/10.1016/S0892-6875(02)00310-2

[60] Pappu, A., Saxena, M., Asolekar, S.R. (2006). Jarosite characteristics and its utilisation potentials. Science of the Total Environment, 359(1-3): 232-243. https://doi.org/10.1016/j.scitotenv.2005.04.024

[61] Ota, M. (1957). Potassium jarosite for fertilizer. Soil Science and Plant Nutrition, 3(1): 139-141. https://doi.org/10.1080/00380768.1957.10431911
[62] Dutrizac, J.E., Chen, T.T. (1984). A mineralogical study of the jarosite phase formed during the autoclave leaching of zinc concentrate. Canadian Metallurgical Quarterly, 23(2): 147-157. https://doi.org/ 10.1179/cmq.1984.23.2.147

[63] Yang, B., Lin, M., Fang, J., Zhang, R., Luo, W., Wang, X., Liao, R., Wu, B., Wang, J., Gan, M., Liu, B., Zhang, Y., Liu, X., Qin, W., Qiu, G. (2020). Ccombined effects of jarosite and visible light on chalcopyrite dissolution mediated by acidithiobacillus ferrooxidans. Science of the Total Environment, 698: 1-11. https://doi.org/10.1016/j.scitotenv.2019.134175

[64] Welch, S.A., Kirste, D., Christy, A.G., Beavis, F.R., Beavis, S.G. (2008). Jarosite dissolution II - reaction kinetics, stoichiometry and acid flux. Chemical Geology, 254:

73-86. https://doi.org/10.1016/j.chemgeo.2008.06.010

[65] Mehra, P., Kumar, S., Thomas, B.S., Gupta, R.C. (2018). Analysis on the hazardous jarosite added concrete. Construction and Building Materials, 191: 253-259. https://doi.org/10.1016/j.conbuildmat.2018.10.006

[66] Kazemi, M.J., Kargar, M., Nowroozi, J., Sepahi, A., Doosti, A., Manafi, Z. (2019). The wide distribution of an extremely thermoacidophilic microorganism in the copper mine at ambient temperature and under acidic condition and its significance in bioleaching of a chalcopyrite concentrate. Revista Argentina de Microbiologia, 51(1): 56-65. https://doi.org/10.1016/j.ram.2017.09.004

[67] Nazari, B., Jorjani, E., Hani, H., Manafi, Z., Riahi, A. (2014). Formation of jarosite and its effect on important ions for Acidithiobacillus ferrooxidans bacteria. Transactions of Nonferrous Metals Society of China, 24: 1152-1160. https://doi.org/10.1016/S1003- 